\title{
Assessing the leaching behavior of different gunshot materials in natural spring waters
}

\author{
Julian Fäth *i] and Axel Göttlein
}

\begin{abstract}
Background: Owing to the high environmental risk of lead-based gunshot, especially as the main source of acute lead poisoning in waterfowl, restrictions on its use in European wetlands are being put into place. In order to assess potential risks of alternative gunshot pellets to aquatic systems, we validated a recently published study that compared the leaching behavior of different game shot materials in an artificial solution and their toxicological effects to Daphnia magna. We therefore investigated the altered leaching of shot materials in natural spring waters.

Results: The different water conditions (geology/redox conditions) had a strong influence on the leaching behavior of the examined shot types. Spring water originating from siliceous bedrock showed the highest concentrations of nearly all leached metals under aerobic conditions. The results were similar to the former study, which used an artificial standardized medium for daphnids.

Conclusions: According to the conducted leaching tests, $\mathrm{Cu}$ - and Zn-based as well as Zn-coated gunshot should be avoided by reason of the high risks they pose to the aquatic environment. Furthermore, the use of Pb-based and $\mathrm{Ni}$ alloyed or -coated game shot also should be hampered owing to their impact on birds or other wildlife. Since some of these shot materials are still on the European market, an effective toxicity screening of alternative gunshot materials is necessary. By conducting standardized leaching tests, in addition to chemical compositional standards and toxicity tests regarding birds, the environmental risks of each game shot would entirely be assessed. The method presented in this study provides a further step for initial ecotoxicological risk assessment of gunshot for aquatic systems, since it additionally assesses minor components, like thin coatings, which also can have a high impact to these ecosystems.
\end{abstract}

Keywords: Hunting, Ammunition, Aquatic systems, Heavy metal, Lead, Copper, Zinc, Tungsten, Bismuth

\section{Background}

Because of mortality of scavenging species after ingesting lead $(\mathrm{Pb})$-contaminated quarry $[14,19,30]$ and the poisoning of waterfowl as a result of the ingestion of $\mathrm{Pb}$ shot instead of natural grit and food [27,34], a general ban on $\mathrm{Pb}$ in game ammunition in the European Union (EU) has been recommended by the European Chemicals Agency [6]. Furthermore, many states worldwide and in particular in Europe (23 countries) already have regulated the use of lead shot [28]. For decades, the effects of lead poisoning in waterfowl, raptors, scavengers and terrestrial

\section{*Correspondence: julian.faeth@tum.de}

Professorship of Forest Nutrition and Water Resources, Technical University of Munich, Hans-Carl-von-Carlowitz-Platz 2, 85354 Freising, Germany birds are highly documented [34]. According to comparative investigations, the oral intake of shot made of nickel $(\mathrm{Ni})$, iron $(\mathrm{Fe})$, tin $(\mathrm{Sn})$, copper $(\mathrm{Cu})$ and tungsten $(\mathrm{W})$ did not lead to a higher mortality of mallards (Anas platyrhynchos) compared with a control, whereas $\mathrm{Pb}$-based shot did cause significantly higher mortality rates $[10,12$, $13,24]$. However, alternatives that are available in the EU, also should be controlled regarding their effects on the environment [42,44], since some of them may also result in ecotoxicological problems. For example, W alloyed with Ni can cause toxic effects in both, humans and the environment (Ni: [8, 35, 36, 41]; W-compounds: [2, 40]). Furthermore, a study by Levonmäki and Kairesalo [22] revealed the potential for high chromium $(\mathrm{Cr})$ loadings to be released into the soil of shooting ranges from steel shot containing up to $27 \% \mathrm{Cr}$. The (eco)toxicological risks of this heavy metal, especially the high carcinogenicity of 
$\mathrm{Cr}(\mathrm{VI})$, are well known $[9,11,45]$ and should not result from such a high $\mathrm{Cr}$ content in steel shot, which is commonly seen as nontoxic. As a result of strong leaching, zinc (Zn)- and $\mathrm{Cu}$-based shot may also negatively impact the terrestrial environment [8]. Moreover, the findings of a first comparative investigation on the leaching behavior of game shot in artificial freshwater and the resulting toxicological effects on Daphnia magna [7] indicate that shot types leaching $\mathrm{Cu}$ or $\mathrm{Zn}$ pose a high risk to the aquatic biocenosis. In that study, shot made of Fe and coated with $\mathrm{Zn}$ released as much $\mathrm{Zn}$ as a pure $\mathrm{Zn}$-based shot and caused nearly $100 \%$ mortality of daphnids, indicating that not only the main component but also alloy components and shot coatings should be considered when regulating the use of game shot materials. In order to avoid encouraging the manufacture, trade and use of the above-mentioned critical substitutes for $\mathrm{Pb}$ shot in the EU, a mandatory toxicity screening of all alternatives should be adopted. As far as legislation would strictly regulate these substitutes, e.g., in the USA and Canada $[43,46]$, the European market would already be free from shot types leaching the above-mentioned critical metals. Although every relevant ecosystem (terrestrial and aquatic habitats, avifauna) should be considered, this study focuses on the aquatic compartment.

Since recent studies have demonstrated that the main component is not always the main driver of the environmentally relevant impact of a shot material $[7,8,35$, 36, 41], standardized experimental leaching tests for particular environments are needed as an important step in ecotoxicological risk assessment. Therefore, the Organization for Economic Cooperation and Development (OECD) provides guidelines for assessing the dissolution of metals in aqueous media [32,33]. These were considered and modified in a hypothesis-driven leaching test described in Fäth et al. [7], representing a worst-case scenario for game shot emitted into aquatic ecosystems. Since that study considered just one standardized artificial freshwater environment adapted to Daphnia magna, we decided to extend the experimental design to obtain information about the leaching behavior of shot subjected to natural waters from different bedrock and with different redox conditions.

Modifying the experimental setup of the former study, we put different game shot materials in natural spring water originating from different bedrock (siliceous and calcareous) under aerobic and anaerobic conditions at four exposure periods. In order to reflect the market situation in the $\mathrm{EU}$, we assessed (i) three conventional $\mathrm{Pb}$ based shots, (ii) one coated Pb-based shot and (iii) seven alternative shots made of $\mathrm{Fe}, \mathrm{Zn}, \mathrm{W}$, bismuth $(\mathrm{Bi})$ and $\mathrm{Cu}$.
Table 1 Overview of investigated shot types

\begin{tabular}{llll}
\hline Shot name & Abbreviation & Major element & Coating \\
\hline Rottweil Waidmannsheil & Waidmannsheil & $\mathrm{Pb}$ & No \\
Rottweil Special 36 & Special & $\mathrm{Pb}$ & No \\
Fiocchi PL 34 & $\mathrm{PL} \mathrm{34}$ & $\mathrm{Pb}$ & No \\
Rottweil Silver Selection & Silver & $\mathrm{Pb}$ & Yes \\
Rottweil Steel Game & Steel Game & $\mathrm{Fe}$ & No \\
Fiocchi Steel Shot & Steel Shot & $\mathrm{Fe}$ & Yes \\
Winchester Blind Side & Blind Side & $\mathrm{Fe}$ & Yes \\
SK Hubertus Zink & Hubertus & $\mathrm{Zn}$ & No \\
Rottweil Ultimate & Ultimate & W & Yes \\
Eley Bismuth Alphamax & Alphamax & $\mathrm{Bi}$ & Yes \\
FOB Sweet Copper & Sweet Copper & $\mathrm{Cu}$ & No \\
\hline
\end{tabular}

For additional information about their full composition see Additional file 1: Data S1

\section{Materials and methods}

\section{Shot types}

In collaboration with the Bavarian Hunting Association, we selected the most relevant ammunition size and shot materials on the European market, giving a total of eleven types of shotgun ammunition (Table 1). Ammunition comprised the following main components: $\mathrm{Pb}, \mathrm{Cu}, \mathrm{Fe}$, $\mathrm{Zn}, \mathrm{W}$ and $\mathrm{Bi}$. The shot cartridges were obtained in size \#2 (3.75 mm diameter), with the exception of two shots (Eley Bismuth Alphamax and Fiocchi PL 34), which were only available with a smaller diameter $(3.5 \mathrm{~mm})$. Since our institute is not licensed to manipulate ammunition components, RUAG Ammotec $\mathrm{GmbH}$ disassembled all cartridges of the unfired shots and provided the contents of metals in each shot type, as well as the presence and thickness of shot coatings (see Additional file 1: Data S1). Since the cartridges of $F O B$ Sweet Copper also contained $\mathrm{Cu}$-coated $\mathrm{Pb}$ shot (12\% of all pellets), the pure $\mathrm{Cu}$ shots were separated to allow a clear assessment of $\mathrm{Cu}$ as a shot material.

\section{Game shot exposure}

To obtain a relative comparison of the leaching behavior of different game shot materials, our experimental setup was based on the aqueous exposure test described by Fäth et al. [7]. This approach was originally influenced by the OECD guidelines for assessing the dissolution/transformation of metals in aqueous media [32, 33 ] and was modified to a high-exposure test as a worstcase scenario. Such a scenario was subjected to shallow water resp. wet spots with only a few millimeters water depth, which are typical habitats of daphnids. On hunting hotspots with a high loading of up to 100 pellets per $\mathrm{m}^{2}$ (more than 100 pellets per each cartridge for this caliber; [7]), a high pellet/water ratio (1 pellet/50 mL) 


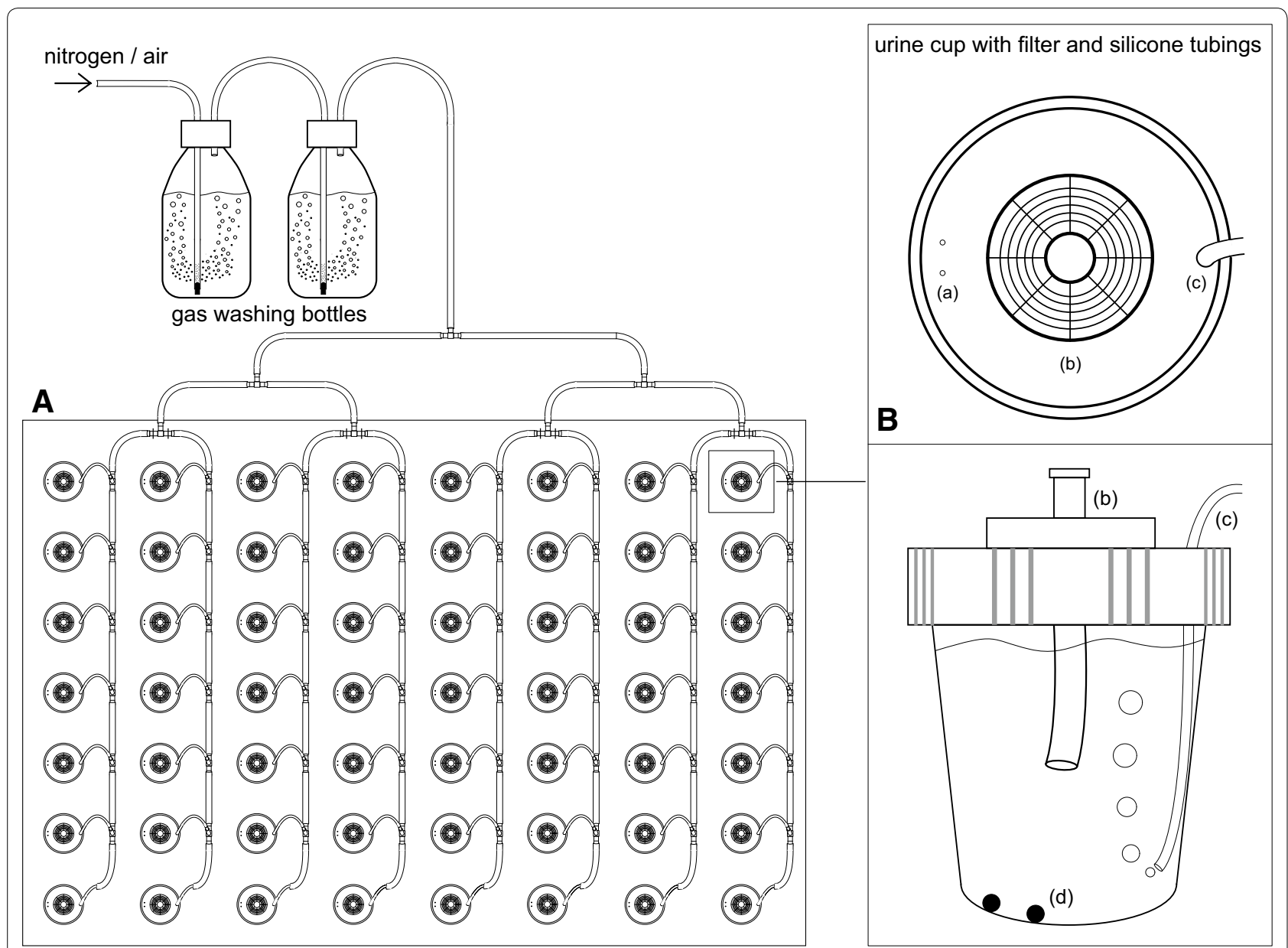

Fig. 1 Experimental setup of the leaching test. A Arrangement of the exposure units during the experiment; $\mathbf{B}$ single exposure unit; (a) punctures for depressurization; (b) membrane filter; (c) silicone tubing; (d) shot pellets

can occur, which was implemented in this study. The leaching test of Fäth et al. [7] comprised a standardized medium termed "Aachener Daphnien Medium" (ADaM; [18]) and thus excluded the effects of natural freshwater with different $\mathrm{pH}$ values and redox conditions. To ensure realistic water properties, we sampled water from two springs in Bavaria (Federal State of Germany) rising from siliceous (Red sandstone in the uplands of Spessart; $49^{\circ} 55^{\prime} 37.9^{\prime \prime} \mathrm{N} 9^{\circ} 23^{\prime} 53.5^{\prime \prime} \mathrm{E} ; \mathrm{pH}$ 6.5) and calcareous (Munich gravel plain; $48^{\circ} 23^{\prime} 39.6^{\prime \prime} \mathrm{N}$ $11^{\circ} 43^{\prime} 23.6^{\prime \prime} \mathrm{E} ; \mathrm{pH} 7.6$ ) bedrock. In order to realize the high-exposure scenario described by Fäth et al. [7], two pellets of each shot type were exposed to $100 \mathrm{~mL}$ of the sampled waters in modified medical urine cups (Fig. 1). To manipulate the redox conditions, the cups were flushed with pre-cleaned air (aerobic conditions) or nitrogen gas (anaerobic conditions) through silicone tubings (c).
To avoid water losses, the gases were water saturated (using wash bottles) prior to entering the cups. A punctuated (a) screw cap allowed the escape of surplus gas while maintaining an almost closed system. For each of the four treatments (siliceous aerobic; siliceous anaerobic; calcareous aerobic; calcareous anaerobic) three replicates and four sampling time points $(1,8,15$ and 22 days) were used, in accordance with Fäth et al. [7]. The experimental setup thus provided short-term and long-term exposure periods, as suggested by the OECD [32, 33]. At each of the four time points, the silicone tubing between the membrane filter (b) (pore diameter: $0.45 \mu \mathrm{m}$ ) and the solution permitted the sampling (with a syringe) of filtered aliquots $(12 \mathrm{~mL})$ for chemical analysis. After sampling, $12 \mathrm{~mL}$ of the respective fresh water was added to each cup.

By applying four natural extrema (water from siliceous and calcareous bedrock under strong aerobic and 


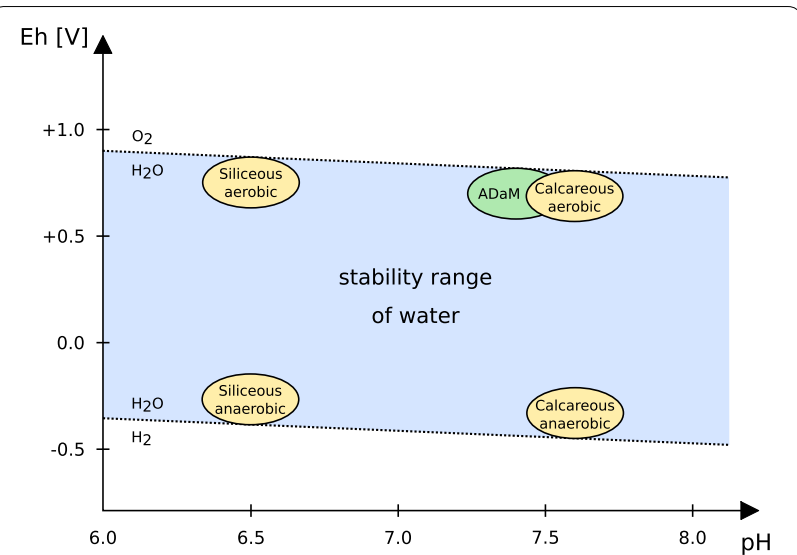

Fig. 2 Schematic placement of the four investigated environments (yellow) as well as the ADaM solution (green) used by Fäth et al. [7] in the stability range of water defined by the redox potential and the $\mathrm{pH}$ value at $298.15 \mathrm{~K}$ and $10^{5} \mathrm{~Pa}$ in an $\mathrm{Eh} / \mathrm{pH}$ chart
Table 2 Limits of the ICP-AES determined by using the blank value method according to DIN 32645: 2008-11

\begin{tabular}{|c|c|c|}
\hline & $\begin{array}{l}\text { LOD } \\
{[\mu \mathrm{mol} / \mathrm{L}]}\end{array}$ & $\begin{array}{l}\text { LOQ } \\
{[\mu \mathrm{mol} / \mathrm{L}]}\end{array}$ \\
\hline As & 0.09 & 0.29 \\
\hline $\mathrm{Cr}$ & 0.03 & 0.09 \\
\hline $\mathrm{Cu}$ & 0.04 & 0.13 \\
\hline $\mathrm{Fe}$ & 0.02 & 0.06 \\
\hline $\mathrm{Mn}$ & 0.01 & 0.02 \\
\hline $\mathrm{Ni}$ & 0.06 & 0.20 \\
\hline $\mathrm{Pb}$ & 0.05 & 0.16 \\
\hline $\mathrm{Sb}$ & 0.06 & 0.19 \\
\hline $\mathrm{Sn}$ & 0.06 & 0.18 \\
\hline $\mathrm{Zn}$ & 0.06 & 0.21 \\
\hline $\mathrm{Bi}$ & 0.08 & 0.27 \\
\hline W & 0.08 & 0.28 \\
\hline
\end{tabular}

LOD: Limit of detection; LOQ: limit of quantification anaerobic conditions), a corridor for metal leaching can be covered (Fig. 2).

\section{Chemical analysis}

The filtered aliquots of $12 \mathrm{~mL}$ were directly analyzed by inductively coupled plasma atomic emission spectrometry (ICP-AES; Genesis, Spectro Kleve) for the concentrations of As, $\mathrm{Cr}, \mathrm{Cu}, \mathrm{Fe}, \mathrm{Mn}, \mathrm{Ni}, \mathrm{Pb}, \mathrm{Sb}, \mathrm{Sn}$ and $\mathrm{Zn}$. These were corrected for the background concentration of blank samples. Eluates of the Ultimate and Alphamax shot types were additionally investigated for the contents of $\mathrm{Bi}$ and W.

For quality assessment of the metal analysis, we measured ten blank values and ten samples of a referenced standard solution. The relative standard deviation (RSD) of the standard solution ranged from three to ten percent for all quantifiable metals in this study. Recovery was between $95 \%$ and $107 \%$. According to the blank value method of DIN 32645: 2008-11 [4], the limits of detection (LOD) and limits of quantification (LOQ) were determined by the threefold, respectively, tenfold standard deviation of the measured blank values (Table 2). In the following, all concentrations are given in $\mu \mathrm{mol} / \mathrm{L}$.

\section{Statistical analyses}

The presented analytical data only reports quantifiable element concentrations (i.e., > LOQ). In order to compare the results with the leaching data of Fäth et al. [7], we merged the first two ( 1 day, 8 days) and last two (15 days, 22 days) exposure periods (short term/long term) and compared the mean metal concentrations for each investigated treatment. To statistically compare the different treatments with the results of Fäth et al. [7], we conducted an analysis of variance (ANOVA) of the leached metals for each exposure period and for every shot type that showed a potentially toxic leaching.

\section{Results}

Leaching in natural spring water

During exposure, the three uncoated $\mathrm{Pb}$ shots Waidmannsheil, Special and PL 34 caused high Pb concentrations and differed in their leaching behavior across the four treatments (Fig. 3a, b). In the water from siliceous bedrock under aerobic conditions, these shots showed the highest $\mathrm{Pb}$ release compared with the other natural waters, whereas the measured values of the calcareous anaerobic variant were almost always below the LOQ. The opposite pattern was observed for leached Sb concentrations, exceeding the LOQ in the calcareous variants. Only relatively low concentrations were found for As in the calcareous aerobic treatment for the shot type Special. By contrast, the coated $\mathrm{Pb}$ shot Silver leached only $\mathrm{Ni}$, with concentrations exceeding the LOQ in all media and highest values in the siliceous anaerobic environment. The coated Fe-based shot Blind Side leached similar $\mathrm{Zn}$ concentrations as the pure zinc shot Hubertus. The $\mathrm{Zn}$ leaching rates in the solutions of Blind Side and Hubertus were highest in the siliceous aerobic variant. Furthermore, Blind Side leached low Cr concentrations, exceeding the LOQ in the water from siliceous bedrock. Pure copper pellets of the shot type Sweet Copper only released quantifiable amounts of $\mathrm{Cu}$ in the aerobic treatments, with the concentrations in the siliceous aerobic variant being highest. Iron, released by 

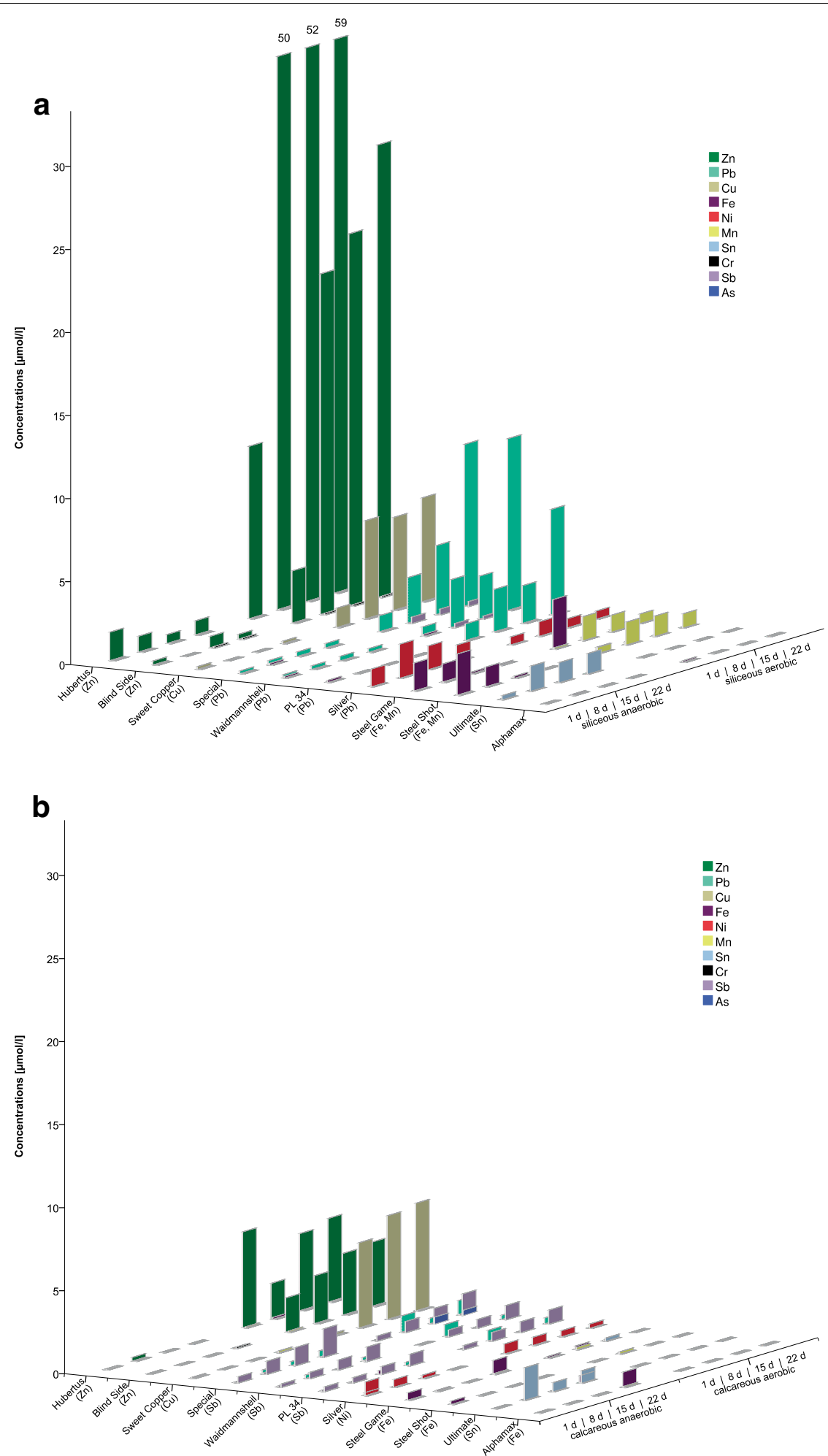

Fig. 3 a Mean concentrations ( $\mu \mathrm{mol} / \mathrm{L} ; n=3$ ) of leached metals exceeding the $L O Q$ (Table 2) after 1, 8, 15 and 22 days of shot exposure in water from siliceous bedrock under aerobic and anaerobic conditions. The mainly leached metal is given in parentheses. $\mathbf{b}$ Mean concentrations ( $\mu$ mol/L; $n=3$ ) of leached metals exceeding the LOQ (Table 2) after 1, 8, 15 and 22 days of shot exposure in water from calcareous bedrock under aerobic and anaerobic conditions. The mainly leached metal is given in parentheses 
Table 3 Mean \pm standard error of relevant heavy metal concentrations $[\mu \mathrm{mol} / \mathrm{L}]$ for each shot type during shortterm ( 1 day; 8 days) and long-term exposure (15 days;
22 days) leaching tests, including the results for ADaM given by Fäth et al. [7]

\begin{tabular}{|c|c|c|c|c|c|c|}
\hline $\begin{array}{l}\text { shot type } \\
\text { (main component) }\end{array}$ & $\begin{array}{l}\text { leached } \\
\text { element }\end{array}$ & ADaM & $\begin{array}{l}\text { siliceous } \\
\text { aerobic }\end{array}$ & $\begin{array}{l}\text { calcareous } \\
\text { aerobic }\end{array}$ & $\begin{array}{l}\text { siliceous } \\
\text { anaerobic }\end{array}$ & $\begin{array}{l}\text { calcareous } \\
\text { anaerobic }\end{array}$ \\
\hline \multicolumn{7}{|c|}{ short term period } \\
\hline \multirow[t]{2}{*}{ PL $34(\mathrm{~Pb})$} & $\mathrm{Pb}$ & $1.81 \pm 0.26$ & $1.77 \pm 0.36$ & $0.32 \pm 0.15$ & $<L O Q$ & $<\mathrm{LOQ}^{\mathrm{a}}$ \\
\hline & $\mathrm{Sb}$ & $<\operatorname{LOD}^{\mathrm{b}}$ & $<\mathrm{LOQ}$ & $0.39 \pm 0.06$ & $<L O Q$ & $0.31 \pm 0.08$ \\
\hline Blind Side (Fe) & $\mathrm{Zn}$ & $13.39 \pm 3.35$ & $11.82 \pm 3.91$ & $2.47 \pm 0.26$ & $0.21 \pm 0.01$ & $<L O D$ \\
\hline Hubertus (Zn) & $\mathrm{Zn}$ & $33.79 \pm 4.56$ & $29.99 \pm 9.02$ & $3.96 \pm 0.81$ & $1.33 \pm 0.19$ & $<L O Q$ \\
\hline Silver $(\mathrm{Pb})$ & $\mathrm{Ni}$ & $0.59 \pm 0.08$ & $0.68 \pm 0.09$ & $0.55 \pm 0.06$ & $1.56 \pm 0.47$ & $0.65 \pm 0.10$ \\
\hline Sweet Copper (Cu) & $\mathrm{Cu}$ & $1.91 \pm 0.51$ & $3.53 \pm 1.06$ & $2.63 \pm 1.12$ & $0.14 \pm 0.01$ & $<L O Q$ \\
\hline Ultimate (W) & Sn & $<L O D$ & $<L O D$ & $<L O D$ & $0.89 \pm 0.29$ & $0.89 \pm 0.44$ \\
\hline \multicolumn{7}{|c|}{ long term period } \\
\hline \multirow[t]{2}{*}{$\mathrm{PL} 34(\mathrm{~Pb})$} & $\mathrm{Pb}$ & $0.60 \pm 0.25$ & $4.30 \pm 1.12$ & $0.20 \pm 0.09$ & $<\mathrm{LOQ}$ & $<\mathrm{LOQ}^{\mathrm{a}}$ \\
\hline & $\mathrm{Sb}$ & $<\mathrm{LOQ}$ & $<\mathrm{LOQ}$ & $0.75 \pm 0.05$ & $<\mathrm{LOQ}$ & $0.59 \pm 0.05$ \\
\hline \multirow[t]{2}{*}{ Blind Side (Fe) } & $\mathrm{Cr}$ & $<L O Q$ & $0.10 \pm 0.00$ & $<\mathrm{LOQ}$ & $0.10 \pm 0.01$ & $<\mathrm{LOQ}$ \\
\hline & $\mathrm{Zn}$ & $34.70 \pm 0.92$ & $24.82 \pm 1.29$ & $3.78 \pm 0.16$ & $0.49 \pm 0.11$ & $<\mathrm{LOD}^{\mathrm{b}}$ \\
\hline Hubertus (Zn) & $\mathrm{Zn}$ & $30.48 \pm 1.79$ & $55.71 \pm 3.75$ & $4.83 \pm 0.15$ & $0.69 \pm 0.10$ & $<\mathrm{LOQ}$ \\
\hline Silver $(\mathrm{Pb})$ & $\mathrm{Ni}$ & $1.34 \pm 0.19$ & $0.52 \pm 0.02$ & $0.31 \pm 0.04$ & $1.20 \pm 0.23$ & $<\mathrm{LOQ}$ \\
\hline Sweet Copper (Cu) & $\mathrm{Cu}$ & $4.11 \pm 0.37$ & $5.92 \pm 0.27$ & $6.35 \pm 0.10$ & $<\mathrm{LOQ}$ & $<\mathrm{LOQ}$ \\
\hline Ultimate (W) & Sn & $<\mathrm{LOQ}$ & $<L O D$ & $<L O D$ & $1.23 \pm 0.07$ & $0.65 \pm 0.08$ \\
\hline
\end{tabular}

LOQ: Limit of quantification; LOD: limit of detection; bold values indicate homogeneous subsets with the significant highest concentrations among the tested environments determined by ANOVA. Grey shading represents those values that exceeded the $\mathrm{EC}_{50}$ for Daphnia magna according to Khangarot and Ray [15]

the shot types Steel Game and Steel Shot, was highest in the siliceous environment, showing decreasing concentrations with increasing exposure time. These two shots also leached quantifiable Mn concentrations, which were greatest in the siliceous aerobic media. The W-based shot Ultimate only caused quantifiable Sn leaching when exposed to an anaerobic environment. Owing to its weak and unspecified metal leaching (measured Fe concentrations only after 22 days of exposure in the calcareous anaerobic variant), the shot type Alphamax could not be associated with quantifiable $\mathrm{Bi}$ release or to the release of other potentially toxic metals relevant to the aquatic environment.

\section{Comparison with the standardized ADaM solution}

Over the short term, ADaM and the siliceous aerobic treatment resulted in the highest levels of $\mathrm{Pb}$ leaching for the conventional $\mathrm{Pb}$ shot $P L$ 34; however, during long-term exposure, this changed to dominant $\mathrm{Pb}$ release solely in the siliceous aerobic treatment (Table 3). The marked $\mathrm{Zn}$ leaching from Blind Side and Hubertus was highest in ADaM (short term: 13.39 and $33.79 \mu \mathrm{mol} / \mathrm{L}$, respectively; long term: 34.70 and $30.48 \mu \mathrm{mol} / \mathrm{L}$, respectively) and the siliceous aerobic solutions (short term: 11.82 and $29.99 \mu \mathrm{mol} / \mathrm{L}$, respectively; long term: 24.82 and $55.71 \mu \mathrm{mol} / \mathrm{L}$, respectively). In addition, the Febased shot Blind Side released very low (but quantifiable) concentrations of $\mathrm{Cr}(0.10 \mu \mathrm{mol} / \mathrm{L})$ in the two siliceous treatments over the long term. Nickel leaching from the coated $\mathrm{Pb}$ shot Silver reached its highest value either in the ADaM media (long term: $1.34 \mu \mathrm{mol} / \mathrm{L}$ ) or in the siliceous anaerobic environment (short term: $1.56 \mu \mathrm{mol} / \mathrm{L}$ ). The highest levels of $\mathrm{Cu}$ leaching from Sweet Copper were measured in the following three solutions: $\mathrm{ADaM}$ (short term: $1.91 \mu \mathrm{mol} / \mathrm{L}$ ), siliceous aerobic (short term: $3.53 \mu \mathrm{mol} / \mathrm{L}$; long term: $5.92 \mu \mathrm{mol} / \mathrm{L}$ ) and calcareous aerobic (short term: $2.63 \mu \mathrm{mol} / \mathrm{L}$; long term: $6.35 \mu \mathrm{mol} / \mathrm{L}$ ). Among these, the siliceous aerobic variant always contained the highest concentrations during both terms. Heavy metal leaching from the $\mathrm{W}$ shot Ultimate was quantifiable for $\mathrm{Sn}$ in the anaerobic environments only (up to $1.23 \mu \mathrm{mol} / \mathrm{L}$ ). Both in the short-term and the long-term period $\mathrm{EC}_{50}$-values for Daphnia magna were exceeded by the metal leaching of Blind Side ( $\mathrm{Zn})$ and 
Hubertus ( $\mathrm{Zn})$ in ADaM as well as in the siliceous aerobic environment and for Sweet Copper $(\mathrm{Cu})$ also in the calcareous aerobic variant.

\section{Discussion}

\section{Justification for the study}

Since the Daphnia test described by Fäth et al. [7] only considered metal leaching in a single standardized but artificial solution, we investigated two natural waters to validate this game shot adapted and comparative approach. This is an important step forward in providing comprehensive test procedures for assessing the potential ecological impact of shot, which has already been claimed by ecologists [42, 43]. Despite the great variety of geological substrates, we minimized the treatments to two extrema of spring water, rising from siliceous and calcareous bedrock. The manipulated oxygen content, which differs between standing and running waterbodies, provides an additional environmental factor. The additional application of sediments and organic compounds was not possible because of the high number of potential treatments that would result. Furthermore, waters with low pH, e.g., sump water, could not be addressed in this study and have to be investigated soon. Nevertheless, a direct impact of different geologies and redox conditions on the leaching behavior of the shot materials in water could be significantly detected.

\section{Patterns of metal leaching}

As expected, the uncoated Pb-based shots Waidmannsheil, Special and PL 34 released quantifiable amounts of $\mathrm{Pb}, \mathrm{Sb}$ and $\mathrm{As}$. The lower $\mathrm{Pb}$ leaching rate under the calcareous aerobic environment probably resulted from surface passivation, through the formation of insoluble lead oxide or lead carbonate around the shot pellet because of a relatively high $\mathrm{pH}$ value of the water [25]. Furthermore, the $\mathrm{N}_{2}$-flushed treatments might have induced resistance against dissolution of the metallic $\mathrm{Pb}$ (electrochemical immunity). By contrast, releases of $\mathrm{Sb}$ and As were highest in the calcareous treatments, which is in line with recent studies $[8,17,38]$ ) and should be considered in dolomite or limestone environments. The coated $\mathrm{Pb}$ shot Silver leached only low concentrations of $\mathrm{Ni}$ in patterns comparable to those of $\mathrm{Pb}$ release, probably resulting from similar electrochemical processes (as mentioned above). As discussed by Fäth et al. [7], Ni originated from the coating. With respect to its metal ion release, Blind Side did not resemble a classical Fe-based shot but was rather similar to the pure $\mathrm{Zn}$ shot Hubertus. As result of the alkaline $\mathrm{pH}$ range (>8.5), which causes surface passivation or immunity of metallic $\mathrm{Zn}$ against dissolution in water [26, 44], high loadings of dissolved $\mathrm{Zn}$ can be released to the aquatic environment (up to $55,71 \mu \mathrm{mol} / \mathrm{L}$; Table 3 ) particularly in waters rising from siliceous bedrock. With a concentration of up to $6.4 \mu \mathrm{mol} / \mathrm{L}, \mathrm{Cu}$ leaching of Sweet Copper exceeded the $\mathrm{EC}_{50}$ values in all aerobic environments and both exposure periods, posing a potential hazard to these waters. The comparatively moderate Fe-(maximum: $3.0 \mu \mathrm{mol} / \mathrm{L}$ ) and Mn-leaching rates (maximum: $1.5 \mu \mathrm{mol} / \mathrm{L}$ ) of Steel Game and Steel Shot should not be considered a real threat to the aquatic environment, since the effect concentrations for relevant organisms $\left(\mathrm{EC}_{50}\right.$ for Daphnia magna of Fe: $129 \mu \mathrm{mol} / \mathrm{L}$ and Mn: $151 \mu \mathrm{mol} / \mathrm{L}$; [15]) are relatively high. Therefore, consideration of these two elements in such a leaching test is not deemed necessary. A similarly low leaching potential was observed for the W-based shot Ultimate, only releasing small amounts of $\mathrm{Sn}$ in anaerobic environments, which is almost negligible considering the relatively low risk of $<1.2 \mu \mathrm{mol} \mathrm{Sn} / \mathrm{L}$ to the environment $\left(\mathrm{EC}_{50}\right.$ for Daphnia magna: $\left.182 \mu \mathrm{mol} / \mathrm{L}\right)$. Owing to the corrosion-resistant properties of metallic Sn [3, 23], rapid surface passivation may be the reason for the nonquantifiable amounts of dissolved $\mathrm{Sn}$ in the aerobic treatments.

\section{Ecotoxicological game shot assessment}

The distinctly higher leaching rates of the three uncoated $\mathrm{Pb}$-based shot types (up to $10.3 \mu \mathrm{mol} / \mathrm{L}$; Fig. 3a) in the siliceous aerobic environment as compared with $\mathrm{ADaM}$ (Table 3), however, did not exceed the $\mathrm{EC}_{50} \mathrm{~Pb}$-threshold for Daphnia magna $(17 \mu \mathrm{mol} / \mathrm{L})$. With regard to the coated $\mathrm{Pb}$ shot Silver, which released $\mathrm{Ni}$ instead of $\mathrm{Pb}$, it is noted that Ni should also be avoided in game ammunition because of its carcinogenic effects on wildlife when present in living tissue [41]. Since the shot coating of Silver may be damaged during firing, additional leaching of $\mathrm{Pb}$ should be expected in reality. Despite the coating a $\mathrm{Pb}$ intoxication of waterfowl $[10,12,13,24]$ has to be assumed as a result of grinding activities and the very acidic environment in their gizzard [37]. Therefore, with respect to the avifauna $\mathrm{Pb}$ in game shot should be avoided. This is even more important because additional $\mathrm{Pb}$ alloy components (e.g., $\mathrm{Sb}$ and $\mathrm{As}$ ) can potentially be leached in alkaline environments.

According to our results, pure Zn shot (Hubertus) and Zn-based coatings (Blind Side) cause hazardous loadings of dissolved $\mathrm{Zn}$ that exceeded the $\mathrm{EC}_{50}$-values for Daphnia magna by far (Table 3). Furthermore, $\mathrm{Zn}$ should be prevented as a component of shot materials for use in hunting since there is a high hazard potential to aquatic [7] and terrestrial environments [8] as well as to avian species [20,21]. The measured concentrations in the aerobic environments containing the Sweet Copper shot were also very critical since they were at least as high as the $\mathrm{Cu}$ concentrations measured in $\mathrm{ADaM}$, which resulted in 
$100 \%$ mortality of daphnids [7]. The high toxicity of $\mathrm{Cu}$ to aquatic wildlife is well known [1, 15, 29, 39, 47]. Pure $\mathrm{Cu}$ must therefore not be used in game shot, which is mainly emitted to wetlands. Furthermore, the admixing of $\mathrm{Cu}$-coated $\mathrm{Pb}$ pellets to pure $\mathrm{Cu}$ shot in $F O B$ Sweet Copper cartridges (which may be considered a consumer fraud) emphasizes the need for legal regulation of game shot materials. Despite the negligible Fe and Mn leaching from Steel Game and Steel Shot, Fe-based shot must not automatically be regarded as nontoxic. The presence of a potentially toxic coating should be evaluated before classifying an Fe-based shot as non-harmful, as underlined by the high $\mathrm{Zn}$ leaching from Blind Side, which led to a similar risk as that of the pure Zn shot Hubertus. In relation to the likely low risk of leached Sn to aquatic systems from the shot type Ultimate, assessing the element content of this W-based alloy is crucial. Since this shot contains up to $10 \% \mathrm{Ni}(\mathrm{S} 1)$, probably resulting in carcinogenic effects on wildlife with shot present in their tissue [41], this kind of alloy should be viewed as critical. However, from an ecotoxicological point of view, Sn seems to be a suitable substitute for $\mathrm{Pb}$ in game shot because of its corrosion-resistant properties. The nonquantifiable metal release of the Bi-based shot type Alphamax suggests little risk to aquatic biota (also see [7]).

\section{Need for obligatory standardized test methods}

According to our results, a general toxicity screening for conventional and alternative game shot should be adopted in the EU. For this purpose, defined methods must be conducted under standardized conditions to guarantee that the impact of metal leaching on aquatic and terrestrial ecosystems is as low as possible. Furthermore, already established methods for testing the toxicity of shot materials for birds, e.g., according to Kimball and Munir [16] which is also implemented in the USFWS [46] protocol, should be adopted in Europe. The study of Fäth et al. [7], however, delivered a reliable proof of concept to investigate metal leaching from game shot in aquatic environments, combined with a first orienting assessment of potential ecotoxicological impacts on this ecosystems. Although the $\mathrm{pH}$ of $\mathrm{ADaM}$ is quite similar to that of the calcareous spring water investigated in this study, it caused high leaching rates that were similar to the siliceous aerobic treatment, except for the case of $\mathrm{Pb}$. This was likely a result of the high ionic strength, resulting from the artificial composites $\left(\mathrm{CaCl}_{2}, \mathrm{NaHCO}_{3}, \mathrm{SeO}_{2}\right.$, synthetic sea salt) in this standardized medium. Currently, the German Institute for Standardization develops methods for testing the minimum requirements for the killing effect of hunting rifle bullets [5], serving as a guideline for respective manufacturers, which could possibly be advanced to a European standard. In analogy to this, a related guideline could be implemented to assess the leaching of potentially hazardous metals from game shot in aquatic systems. Since the properties of natural waters are not reproducible, we suggest the ADaM solution and a flushing of the cups with precleaned air as a standardized worst-case simulation for the aquatic environment. Regarding the broad availability of $\mathrm{EC}_{50}$-values for Daphnia magna [15, 31], it is sufficient to evaluate the leached metal concentrations using these literature thresholds without conducting a real toxicity test. By providing chemical compositional standards for alternatives to $\mathrm{Pb}$, which were inter alia derived from the extremely complex USFWS [46] test protocol, Thomas [42] recently argued for a quite simple screening of alternative game shot materials. With regard to the detected $\mathrm{Cu}$-coated $\mathrm{Pb}$ pellets in the FOB Sweet Copper cartridge, this would be a first step to a legal regulation of $\mathrm{Pb}$ substitutes in Europe. Nevertheless, the procedures according to USFWS [46] neglect marginally contained elements such as the Zn coating (thickness: up to $3 \mu \mathrm{m}$; S1) of the Fe-based shot Blind Side. This small amount (maximum $0.33 \%$ mass fraction) would not exceed the suggested $1 \%$ limit for $\mathrm{Zn}$ but dominates the leaching of toxic ions, resulting in 100\% mortality of Daphnia magna [7]. By conducting standardized leaching tests, the risks of each game shot material for terrestrial and aquatic habitats could be comprehensively assessed, including the effects caused by coatings. Furthermore, the toxicity of European game shot materials to avian species also has to be controlled.

\section{Conclusions}

According to the leaching tests, $\mathrm{Cu}$ - and $\mathrm{Zn}$-based as well as $\mathrm{Zn}$-coated gunshot should be hampered by reason of the high risks they pose to the aquatic environment. Referring to other recently published studies (see chapter 4.3), the use of $\mathrm{Pb}$-based and $\mathrm{Ni}$-alloyed or -coated game shot also should be avoided owing to their impact on birds or other wildlife. In our leaching tests, the different water conditions (geology/redox conditions) caused marked differences in the amounts of leached metals among the examined shot types. The natural spring water from siliceous bedrock under aerobic conditions showed the highest concentrations for all alternative metals among the four treatments that were quite similar to the results of the former study using a standardized medium. We therefore suggest the use of the reproducible ADaM solution for future game shot adapted leaching tests to yield a standardizable worst-case scenario. In addition to the total chemical composition, this method could serve as a further test 
for conducting initial ecotoxicological risk assessments of game shot materials for aquatic systems. As shown by our leaching tests, other minor components like coatings are of great importance for the environmental impact of game shot.

\section{Supplementary information}

Supplementary information accompanies this paper at https://doi. org/10.1186/s12302-019-0249-2.

Additional file 1: Data S1. Element content [\%] of the investigated game shot materials and thickness of a coating provided by RUAG Ammotec $\mathrm{GmbH}$ after disassembling all selected cartridges. Since the cartridges of FOB Sweet Copper contained pure $\mathrm{Cu}$ - and $\mathrm{Cu}$-coated $\mathrm{Pb}$ pellets, the content is presented for the two shot types of this cartridge.

\section{Abbreviations}

ADaM: "Aachener Daphnien Medium"; Alphamax: Eley Bismuth Alphamax; As: arsenic; Bi: bismuth; Blind Side: Winchester Blind Side; Cr: chromium; Cu: copper; $\mathrm{EC}_{50}$ : half maximal effective concentration; ECHA: European Chemicals Agency; EU: European Union; Fe: iron; Hubertus: SK Hubertus Zink; ICP-AES: inductively coupled plasma atomic emission spectrometry; LOD: limit of detection; LOQ: limit of quantification; Mn: manganese; Ni: nickel; OECD: Organization for Economic Cooperation and Development; Pb: lead; PL 34: Fiocchi PL 34; Sb: antimony; Silver: Rottweil Silver Selection; Sn: tin; Special: Rottweil Special 36; Steel Game: Rottweil Steel Game; Steel Shot: Fiocchi Steel Shot; Sweet Copper: FOB Sweet Copper; Ultimate: Rottweil Ultimate; W: tungsten; Waidmannsheil: Rottweil Waidmannsheil.

\section{Acknowledgements}

We are grateful for the support by RUAG Ammotec GmbH which disassembled all cartridges and provided additional information on the shot pellets. We also acknowledge support by the Bavarian Hunting Association (BJV) in selecting different types of game shot. We further thank the professional proofreading service provided by the TUM Graduate School to improve the language of the manuscript.

\section{Authors' contributions}

JF performed the experiments, was involved in the conception, design, analysis and interpretation of the data and wrote the paper. AG headed the study, made substantial contributions to the conception, design, analysis and interpretation of the data, and substantially improved the manuscript. Both authors read and approved the final manuscript.

\section{Funding}

The study was funded by the hunting license fee of the Bavarian State Ministry for Nutrition, Agriculture and Forestry (StMELF). This work was supported by the German Research Foundation (DFG) and the Technical University of Munich (TUM) in the framework of the Open Access Publishing Program.

\section{Availability of data and materials}

The datasets used and/or analyzed during the current study are available from the corresponding author on reasonable request.

\section{Ethics approval and consent to participate}

Not applicable.

\section{Consent for publication}

Not applicable.

\section{Competing interests}

The authors declare that they have no competing interests.

Received: 21 June 2019 Accepted: 21 August 2019

Published online: 18 September 2019

\section{References}

1. Connon RE, Beggel S, D'Abronzo LS, Geist JP, Pfeiff J, Loguinov AV, Vulpe CD, Werner I (2011) Linking molecular biomarkers with higher level condition indicators to identify effects of copper exposures on the endangered delta smelt (Hypomesus transpacificus). Environ Toxicol Chem 30:290-300. https://doi.org/10.1002/etc.400

2. Datta S, Vero SE, Hettiarachchi GM, Johannesson K (2017) Tungsten contamination of soils and sediments: current state of science. Curr Pollut Rep 3:55-64. https://doi.org/10.1007/s40726-016-0046-0

3. Dettner HW (1959) Vergleichende Untersuchung der korrosionsschützenden Wirkung von Zink-Cadmium und Zinnüberzügen auf Stahl. Mater Corros 10:321-326

4. Deutsches Institut für Normung-DIN (2008) Chemical analysis-decision limit, detection limit and determination limit under repeatability conditions-terms, methods, evaluation. DIN 32645:2008-11. Deutsches Institut für Normung, Beuth Verlag GmbH, Berlin

5. Deutsches Institut für Normung_DIN (2017) Geschäftsplan für ein DIN SPEC-Projekt nach dem PAS-Verfahren zum Thema "Mindestanforderungen an Jagdbüchsengeschosse". https://www.din.de/de/forschungund-innovation/din-spec/alle-geschaeftsplaene/wdc-beuth:din21:28107 3673/pdf-2780179. Accessed 12 June 2019

6. European Chemicals Agency_ECHA (2018) ECHA identifies risks to terrestrial environment from lead ammunition. https://echa.europa.eu/de/-/ echa-identifies-risks-to-terrestrial-environment-from-lead-ammunition. Accessed 12 June 2019

7. Fäth J, Feiner M, Beggel S, Geist J, Göttlein A (2018) Leaching behavior and ecotoxicological effects of different game shot materials in freshwater. Knowl Manage Aquat Ecosyst. https://doi.org/10.1051/kmae/2018009

8. Fäth J, Göttlein A (2017) Comparative investigation of the metal leaching from conventional and alternative game shot in a percolation experiment. Allg Forst Jagdztg 188:222-232. https://doi.org/10.23765/afjz0 002016

9. Freeman NC, Stern AH, Lioy PJ (1997) Exposure to chromium dust from homes in a chromium surveillance project. Arch Environ Health 52:213-219. https://doi.org/10.1080/00039899709602889

10. Grandy JW, Locke LN, Bagley GE (1968) Relative toxicity of lead and five proposed substitute shot types to pen-reared mallards. J Wildl Manage 32:483-488. https://doi.org/10.2307/3798926

11. International Agency for Research on Cancer-IARC (1990) Chromium and chromium compounds. In: IARC Working Group on the Evaluation of Carcinogenic Risks to Humans (ed) Monographs on the evaluation of carcinogenic risks to humans, vol 49. IARC Scientific Publications, Lyon, pp 49-256

12. Irby HD, Locke LN, Bagley GE (1967) Relative toxicity of lead and selected substitute shot types to game farm mallards. J Wildl Manage 31:253-257. https://doi.org/10.2307/3798314

13. Kelly ME, Fitzgerald SD, Aulerich RJ, Balander RJ, Powell DC, Stickle RL, Stevens W, Cray C, Tempelman RJ, Bursian SJ (1998) Acute effects of lead, steel, tungsten-iron, and tungsten-polymer shot administered to game-farm mallards. J Wildlife Dis 34:673-687. https://doi. org/10.7589/0090-3558-34.4.673

14. Kenntner N, Tataruch F, Krone O (2001) Heavy metals in soft tissue of white-tailed eagles found dead or moribund in Germany and Austria from 1993 to 2000. Environ Toxicol Chem 20:1831-1837. https://doi. org/10.1002/etc.5620200829

15. Khangarot BS, Ray PK (1989) Investigation of correlation between physicochemical properties of metals and their toxicity to the water flea Daphnia magna straus. Ecotox Environ Safe 18:109-120. https://doi. org/10.1016/0147-6513(89)90071-7

16. Kimball WH, Munir ZA (1971) The corrosion of lead shot in a simulated waterfowl gizzard. J Wildlife Manage 35:360-365

17. Klitzke S, Lang F (2009) Mobilization of soluble and dispersible lead arsenic, and antimony in a polluted, organic-rich soil - effects of $\mathrm{pH}$ increase and counterion valency. J Environ Qual 38:933-939. https://doi. org/10.2134/jeq2008.0239

18. Klüttgen B, Dülmer U, Engels M, Ratte HT (1994) ADaM, an artificial freshwater for the culture of zooplankton. Water Res 28:743-746. https://doi. org/10.1016/0043-1354(94)90157-0

19. Krone O, Kenntner N, Tataruch F (2009) Gefährdungsursachen des Seeadlers (Haliaeetus albicilla L. 1758). Denisia 27:139-146 
20. Levengood JM, Sanderson GC, Anderson WL, Foley GL, Skowron LM, Brown PW, Seets JW (1999) Acute toxicity of ingested zinc shot to gamefarm mallards Illinois Natural History Survey. Bulletin 36:1-36

21. Levengood JM, Sanderson GC, Anderson WL, Foley GL, Brown PW, Seets JW (2000) Influence of diet on the hematology and serum biochemistry of zinc-intoxicated mallards. J Wildlife Dis 36:111-123

22. Levonmäki M, Kairesalo T (2001) Do steel shots raise a chromium problem on shooting range areas? ISSF News 5:9-10

23. Li H, Yu H, Zhou T, Yin B, Yin S, Zhang Y (2015) Effect of tin on the corrosion behavior of sea-water corrosion-resisting steel. Mater Design 84:1-9. https://doi.org/10.1016/j.matdes.2015.06.121

24. Locke LN, Irby HD, Bagley GE (1967) Histopathology of mallards dosed with lead and selected substitute shot. Bull Wildl Dis Assoc 3:143-147. https://doi.org/10.7589/0090-3558-3.4.143

25. Lyon S (2010) Corrosion of lead and its alloys. Corrosion and Protection Center, Manchester. https://doi.org/10.1016/B978-044452787-5.00098-6

26. Macdonald DD, Ismail KM, Sikora E (1998) Characterization of the passive state on zinc. J Electrochem Soc 145:3141-3149. https://doi. org/10.1149/1.1838777

27. Martinez-Haro M, Taggart MA, Green AJ, Mateo R (2009) Avian digestive tract simulation to study the effect of grit geochemistry and food on Pb shot bioaccessibility. Environ Sci Technol 43:9480-9486. https://doi. org/10.1021/es901960e

28. Mateo R, Kanstrup N (2019) Regulations on lead ammunition adopted in Europe and evidence of compliance. Ambio. https://doi.org/10.1007/ s13280-019-01170-5

29. Mount DI, Stephan CE (1969) Chronic toxicity of copper to the fathead minnow (Pimephales promelas) in soft water. J Fish Res Board Can 26:2449-2457. https://doi.org/10.1139/f69-236

30. Müller K, Altenkamp R, Brunnberg L (2007) Morbidity of free-ranging white-tailed sea eagles (Haliaeetus albicilla) in Germany. J Avian Med Surg 21:265-274. https://doi.org/10.1647/2007-001r.1

31. Okamoto A, Yamamuro M, Tatarazako N (2015) Acute toxicity of 50 metals to Daphnia magna. J Appl Toxicol 35:824-830. https://doi.org/10.1002/ jat.3078

32. Organization for Economic Cooperation and Development-OECD (2001) Guidance document on transformation/dissolution of metals and metal compounds in aqueous media. OECD series on testing and assessment, number 29

33. Organization for Economic Cooperation and Development-OECD (2008) Considerations regarding applicability of the guidance on transformation/dissolution of metals and metal compounds in aqueous media. OECD series on testing and assessment, number 98

34. Pain DJ, Mateo R, Green RE (2019) Effects of lead from ammunition on birds and other wildlife: a review and update. Ambio 48:935-953. https:// doi.org/10.1007/s13280-019-01159-0
35. Paulsen P, Sager M (2017) Nickel and copper residues in meat from wild artiodactyls hunted with nickel-plated non-lead rifle bullets. Eur J Wildlife Res. https://doi.org/10.1007/s10344-017-1123-4

36. Paulsen P, Bauer F, Sager M, Schuhmann-Irschik I (2015) Model studies for the release of metals from embedded rifle bullet fragments during simulated meat storage and food ingestion. Eur J Wildl Res 61:629-633. https://doi.org/10.1007/s10344-015-0926-4

37. Scheuhammer AM, Norris SL (1996) The ecotoxicology of lead shot and lead fishing weights. Ecotoxicology 5:279-295. https://doi.org/10.1007/ Bf00119051

38. Schwarz D, Fäth J, Göttlein A (2015) Development of a standardized test method for investigating the environmental solubility of metal ions from materials used in rifle bullets. Allg Forst Jagdztg 186:175-187

39. Shuhaimi-Othman M, Yakub N, Ramle NA, Abas A (2011) Toxicity of metals to a freshwater ostracod: stenocypris major. J Toxicol. https://doi. org/10.1155/2011/136104

40. Strigul N, Koutsospyros A, Arienti P, Christodoulatos C, Dermatas D, Braida W (2005) Effects of tungsten on environmental systems. Chemosphere 61:248-258. https://doi.org/10.1016/j.chemosphere.2005.01.083

41. Thomas VG (2016) Elemental tungsten, tungsten-nickel alloys and shotgun ammunition: resolving issues of their relative toxicity. Eur J Wildl Res 62:1-9. https://doi.org/10.1007/s10344-015-0979-4

42. Thomas VG (2019) Chemical compositional standards for non-lead hunting ammunition and fishing weights. Ambio 48:1072-1078. https://doi. org/10.1007/s13280-018-1124-x

43. Thomas VG, Guitart R (2003) Evaluating non-toxic substitutes for lead shot and fishing weights. Environ Policy Law 33:150-154

44. Thomas S, Birbilis N, Venkatraman M, Cole I (2012) Corrosion of zinc as a function of $\mathrm{pH}$. Corrosion 68:1-9. https://doi.org/10.5006/1.3676630

45. Urbano A, Rodrigues C, Alpoim M (2008) Hexavalent chromium exposure, genomic instability and lung cancer. Gene Ther Mol Biol 12:219-238

46. USFWS (1997) Migratory bird hunting: Revised test protocol for nontoxic approval procedures for shot and shot coating; 50 CFR Part 20; Department of the Interior. U.S. Fish and Wildlife Service. Washington, DC Federal Register 62:63608-63615

47. Vardy DW, Santore R, Ryan A, Giesy JP, Hecker M (2014) Acute toxicity of copper, lead, cadmium, and zinc to early life stages of white sturgeon (Acipenser transmontanus) in laboratory and Columbia River water. Environ Sci Pollut Res 21:8176-8187. https://doi.org/10.1007/s1135 6-014-2754-6

\section{Publisher's Note}

Springer Nature remains neutral with regard to jurisdictional claims in published maps and institutional affiliations.

\section{Submit your manuscript to a SpringerOpen ${ }^{\odot}$ journal and benefit from:}

- Convenient online submission

- Rigorous peer review

Open access: articles freely available online

- High visibility within the field

- Retaining the copyright to your article

Submit your next manuscript at springeropen.com 